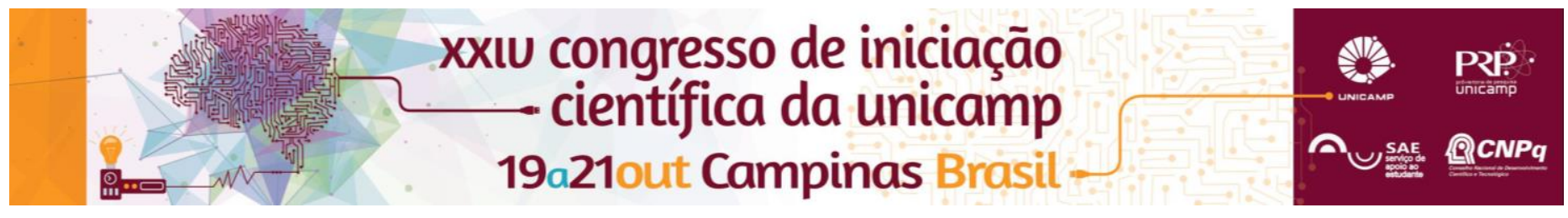

\title{
A influência da música no comportamento do condutor de veículos.
}

\author{
Bruno I. T. Nagamatu, Prof ${ }^{a}$. Dr. ${ }^{a}$ Maria T. Françoso (orientadora), Pablo Y. Y. Kubo (co-orientador)
}

\begin{abstract}
Resumo
O objetivo desta pesquisa é analisar se há influência da música no comportamento do condutor de veículos. A ideia surgiu a partir do conhecimento da existência, em outros países, de pavimentos com ranhuras, nas quais, se o motorista percorrer o trecho na velocidade estabelecida, perceberá a musicalidade. A partir disto, fez-se um estudo bibliográfico sobre a música e o comportamento humano no trânsito para compreender a relação que existe entre estes dois fatores. Para que a pesquisa não se tornasse somente teórica, foi aplicado um questionário visando confrontar as informações obtidas na bibliografia disponível com as respostas dos voluntários. O resultado desta consulta mostrou que aproximadamente $56 \%$ dos voluntários que participaram da pesquisa responderam que há influência da música no comportamento humano durante a condução de veículos. Com este estudo espera-se que a conclusão auxilie na melhoria da gestão do tráfego viário favorecendo os órgãos interessados
\end{abstract}

Palavras-chave: Música, Motorista, Comportamento.

\section{Introdução}

A situação do trânsito na contemporaneidade em grandes cidades brasileiras é um fenômeno complexo que interfere na saúde emocional das pessoas, o que faz com que estudos relacionados a este tema sejam de fundamental importância. A fim de analisar fatores que impactam positiva ou negativamente no comportamento do condutor do veículo nos percursos, este projeto pesquisou sobre a possível influência da música no comportamento do motorista.

\section{Resultados e Discussão}

Através do estudo bibliográfico foram encontrados fortes indícios da influência da música no comportamento do condutor de veículos. Dois trabalhos foram mais relevantes sobre o tema. No primeiro, os participantes foram separados em dois grupos (com e sem a presença de música) e dirigiam em um simulador. A simulação ocorreu de forma a levar o motorista a situações extremas. A análise foi feita a partir de registro verbal dos participantes enquanto estavam no simulador. $O$ resultado obtido foi de que ouvir música aumentou o esforço mental do condutor, independente da situação (REVIDE, 2015). No segundo, realizado pela Royal Automobile Club Foundation for Motoring (Fundação destinada a pesquisas de mobilidade, economia, desenvolvimento e segurança em rodovias) baseou-se na Cavalgada das Valquírias de Richard Wagner. Dentre os pesquisados $60 \%$ reconhecem o poder da música no humor (que está intimamente ligado à forma de dirigir) e $15 \%$ admitem a alteração da velocidade. De acordo com o estudo estes fatos ocorrem porque a música tem o controle da percepção real do tempo e quanto maior sua intensidade, mais atenção é dada as notas e harmonias (COM SHALOM, 2014),

Para confirmar as informações anteriores, fez-se uma pesquisa com voluntários que preencheram um questionário elaborado com ferramentas do Google form, obtendo-se as seguintes informações:

- a pesquisa envolveu motoristas com idade entre 21 a 72 anos;

- $\quad 70 \%$ tem nível de escolaridade superior ou pós-graduação;

- $\quad$ aproximadamente $93 \%$ dos participantes dirigem no meio urbano e em rodovias;

- $\quad$ maior parte das viagens são de lazer (86,9\%), porém muitos fazem por motivos de trabalho $(62,3 \%)$ e estudo $(62,1 \%)$.
De acordo com a Figura 1 foi possível validar a pesquisa a premissa que a música influencia no comportamento do motorista.

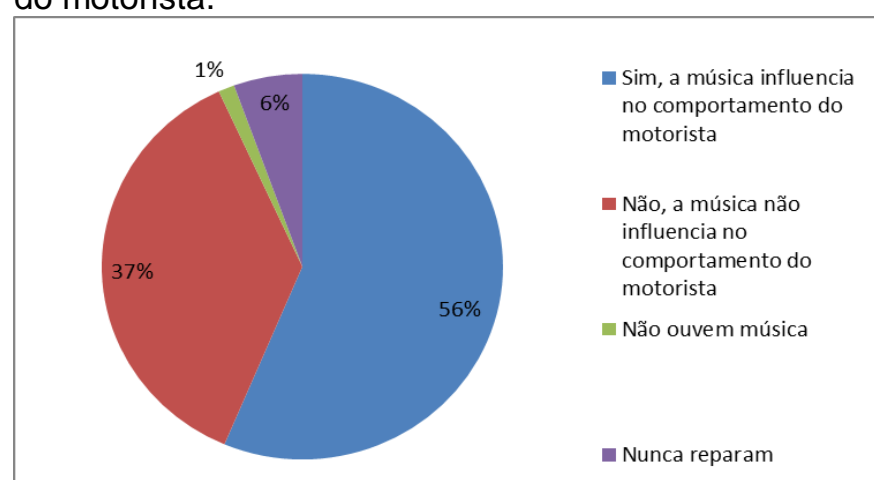

Figura 1: Resposta dos voluntários sobre a influência da música no comportamento do motorist

\section{Conclusões}

A pesquisa com voluntários serviu para comprovar o que foi constatado na revisão bibliográfica. Dentre as respostas à questão, se o voluntário já havia notado alguma alteração em seu modo de dirigir de acordo com o estilo musical, uma parte delas foi negativa (37\%). Isto não contradiz a conclusão anterior, já que a influência pode existir sem que a pessoa repare. Por outro lado, mais de $50 \%$ afirmaram a existência dessa influência com argumentos plausíveis. A maior alteração sentida pelos motoristas é a variação da velocidade conforme o estilo escutado (por exemplo, música clássica associase a uma direção com velocidade reduzida enquanto o rock proporciona um ritmo acelerado).

Observação: por envolver seres humanos esta pesquisa passou pela aprovação pelo Comitê de Ética em Pesquisa obtendo o TERMO DE CONSENTIMENTO LIVRE E ESCLARECIDO (TCLE) com Número do CAAE: 48162015.9 .0000 .5404

COM SHALOM, redação. Motorista, você é aquilo que você ouve. São Paulo: Com Shalom, 2014. Disponível em: <http://www.comshalom.org/motorista-vocee-aquilo-que-voce-ouve/>. Acesso em: 13 out. 2015.

REVIDE, Redação. Música e celular no trânsito: A vida dança. Ribeirão Preto: Revide, 2015. Disponível em: <http://www.revide.com.br/blog/jose-aparecidoda/musica-e-celular-no-transito-vida-danca/> . Acesso em: 13 out. 2015. 